2 Research Square

\title{
Microbial colonisation, the missing link: from airborne dispersal to integration within the soil community.
}

\author{
Lucie Malard ( $\square$ lucie.malard@unil.ch ) \\ University of Lausanne https://orcid.org/0000-0001-9988-2127 \\ David A Pearce \\ Northumbria University
}

\section{Research}

Keywords: Microbial colonisation, airborne dispersal, snow, soils, Arctic ecosystems, bacterial diversity

Posted Date: February 3rd, 2021

DOI: https://doi.org/10.21203/rs.3.rs-168887/v1

License: (9) (7) This work is licensed under a Creative Commons Attribution 4.0 International License. Read Full License 


\section{Abstract}

\section{Background}

Global dispersal of microorganisms primarily occurs through airborne transport. Airborne microorganisms can travel thousands of kilometres and be deposited in the most remote places on Earth, from the Arctic to Antarctica, with the potential of invasion and colonisation. The first stage of microbial colonisation is deposition into a new ecosystem. However, how and under what circumstances such deposited microorganisms might successfully colonise a new environment is yet to be determined. Using the Arctic snowpack as a model system, we investigated the colonisation potential of snow derived bacteria deposited onto Arctic soils during and after snowmelt using laboratory-based microcosm experiments set-up to mimic realistic environmental conditions. We tested different melting rate scenarios to evaluate the influence of increased precipitation (via the increase of bacterial inputs and ecosystem disturbance) as well as the influence of soil pH (as the key driver of soil diversity) on bacterial communities and on the colonisation potential.

\section{Results}

We observed several candidate colonisations in all experiments; however, the number of potentially successful colonisation was higher in acidoneutral soils, at the average snowmelt rate measured in the Arctic. While the higher melt rate increased the total number of potentially invading bacteria, it did not promote colonisation. Instead, persistence decreased with time and most potential colonists were not identified by the end of the experiments. On the other hand, soil pH appeared as a determinant factor impacting invasion and subsequent colonisation. In acidic and alkaline soils, bacterial persistence with time was lower than in acidoneutral soils, as was the number of potentially successful colonisations.

\section{Conclusions}

This is the first study to investigate bacterial colonisation using the snowpack as a model system, and to demonstrate the low rate of potentially successful colonisations of soil by invading bacteria. It suggests that local soil properties might have a greater influence on the colonisation outcome than increased precipitation or ecosystem disturbance.

\section{Background}

Global dispersal of microorganisms has primarily been shown to occur through airborne transport via the aerosolisation of particles [1]. Once airborne, microorganisms can travel thousands of kilometres [2-5] and be deposited to the most remote places on Earth, from the Arctic [6-8], to Antarctica [9-12]. While microorganisms were once considered to be ubiquitously distributed with limitless dispersal capability [13], recent studies have shown that microorganisms are not cosmopolitan and the role of ecological drift and dispersal limitation in their distribution is significant [14-17]. Therefore, airborne microorganisms have the potential to invade and colonise all ecosystems across the globe.

The first step of microbial colonisation is deposition within the environment itself $[18,19]$. This deposition process is generally categorised as 'wet' or 'dry' deposition. Dry deposition occurs following adherence to buildings, plants, water or soil surfaces, while wet deposition is caused by precipitation events such as rain or snow $[1,20]$. While the constant deposition of microorganisms into new environments is accepted and has been demonstrated [20-22], whether the deposited microorganisms become established and colonise the new environment long-term is still subject to debate. Only a few studies to date have investigated these questions, including a study demonstrating the quick colonisation of sterile soils by airborne microorganisms [23], and another suggesting that dispersal via rainfall altered the soil microbial response to drought without actively demonstrating microbial colonisation [24].

The Arctic snowpack is an ideal model with which to study colonisation following wet deposition (by snowfall) since it covers the Arctic tundra for 8 to 10 months of the year while also isolating the soil from outside influence [25]. The snowpack acts as an ephemeral transition ecosystem for airborne microorganisms. Indeed, although the snowpack is seeded by airborne microorganisms, its own unique microbial community develops over time [6, 26-28]. The snowpack community is well adapted to surrounding environmental conditions [29-31], one of the key factors in successful colonisation [18, 19]. Once the snow starts to melt, the run-off travels vertically under gravity on flat terrain, to reach the frozen soil layer and infiltrate the soil [26, 32, 33]. However, the percolation of meltwater is a complex process influenced by soil properties such as temperature, moisture or the presence of ice, but also by the rate of snowmelt [32,33]. The snowpack is a major source of potential colonists as it supports between $10^{1}$ and $10^{4}$ microbial cells per mL [34-37]. Snowmelt also creates a peak in nutrient and solute availability in soils [26, 38-40]. This resource pulse may facilitate the colonisation of soils by snow microorganisms [41]. Furthermore, ecosystem disturbance, such as the sudden addition of water [42, 43], may promote successful colonisation [44, 45]. Therefore, snowmelt may be an opportunity for snow microorganisms to establish in rich and diverse soil communities, which would otherwise be difficult to colonise [46]. Generally, studies on microbial invasion and colonisation investigate a single (or very few) invader taxa inoculated at a high density into manipulated communities [23, 41, 47-50]. In this study, we investigated changes in soil bacterial communities during snowmelt and evaluated the colonisation potential of snow bacteria deposited into Arctic soils during and after snowmelt using microcosm experiments. Invading (snow) and invaded (soil) communities were not manipulated in order to examine changes in abundance, alpha and beta diversity with snowmelt and assess the frequency of potentially successful colonisation events from a realistic inoculation scenario into natural soil communities.

The first set of experiments evaluated the influence of increased precipitation on the colonisation potential by using different melt rate scenarios. A seasonal average and a fast saturating snowmelt rate were simulated to test the hypotheses that increased colonisation would be observed in the soils influenced by a fast flow rate due to a higher number of microorganisms deposited as well as increased ecosystem disturbance (analogue to increased precipitation). Indeed, under the current climate trend, precipitation (either rain or snowfall) is expected to increase in the region [51, 52], and the resulting 
deeper snowpack may melt faster due to higher temperatures [53]. Whether such an increase in microorganisms and available water as a result of a deeper snowpack will influence the colonisation success remains to be determined.

The second set of experiments investigated the colonisation potential of microorganisms deposited into soil ecosystems with different pH ranges. In Arctic soils, as elsewhere, $\mathrm{pH}$ is the primary driver of microbial community structure and diversity $[14,17,54,55]$, demonstrating that climatic conditions are not the only abiotic factor invaders have to adapt to. The influence of soil $\mathrm{pH}$ on the colonisation potential during average snowmelt rates was evaluated to test the hypothesis that increased colonisation would be observed in acidoneutral soils compared to acidic and alkaline soils. In many ways, acidic and alkaline soils are considered harsh environments requiring a wide range of adaptations [56-58]. Although microorganisms within the snow can be expected to be well adapted to climatic conditions [29-31], whether they have the capacity to adapt to harsh physicochemical properties or to fast changing environmental conditions to colonise soils remains unknown.

\section{Methods}

\section{Approach}

In all experiments, melted snow was input into soil columns and after percolation, the outflow was recovered [Fig. 1]. In the first set of experiments, only flow rate was manipulated (at acidoneutral soil pH) to evaluate the influence of increased precipitation (using snowmelt rate as a proxy). In the second set of experiments, only soil pH was manipulated (at constant average flow rate) to evaluate the influence of soil pH on the colonisation potential of snow bacteria into soils.

The snowmelt period in the Arctic lasts anywhere between 7 to 30 days, with an average of 15 to 20 days [59, 60]. Here, melted snow was introduced to the system every day for 14 days to simulate this snowmelt period, followed by 15 days snow-free to simulate the post-melt season. All experiments were conducted at $4^{\circ} \mathrm{C}$ to simulate Arctic climatic conditions. However, they were kept in the dark, unlike summer Arctic conditions, to avoid the formation of cyanobacterial mats and to avoid a light regime change after storage in the dark. Indeed, differentiating the impact of light and water regime change would have been difficult. Bacterial communities within each component (snow, soil, outflow) were monitored with time using qPCR and 16S rRNA gene amplicon sequencing.

\section{Sample collection and properties}

The soil used for microcosm experiments was collected in Adventdalen $\left(78^{\circ} 10^{\prime} 12^{\prime \prime} \mathrm{N}, 16^{\circ} 3^{\prime} 0^{\prime \prime} \mathrm{E}\right)$, Svalbard in July 2018 , from the top $15 \mathrm{~cm}$ using ethanolcleaned trowels and Whirl-pak bags (Nasco, WI, USA). Plant roots and rocks were removed manually in a class II biological safety cabinet (ESCO, Singapore), soil samples were homogenised and stored before transportation to the United Kingdom for further analysis. $1 \mathrm{~g}$ of soil was also frozen at $-20^{\circ} \mathrm{C}$ for DNA extraction and later referred to as day of field sampling (DS). The stored soil was passed through a $1.5 \mathrm{~cm}$ sterilised sieve in a class II biological safety cabinet (ESCO) to remove large organic matter and larger soil particles. $\mathrm{pH}$, conductivity, moisture and total organic carbon were measured in the laboratory (Table S1) using the same methods as Malard et al. [17]. The snow used for microcosms was collected in Whirl-pak bags (Nasco) using ethanol-cleaned shovels, close to Mine 7 in Svalbard in July 2018. The snow was left to melt at room temperature, transferred to sterile containers and preserved at $4^{\circ} \mathrm{C}$ until transportation to the United Kingdom. To analyse the bacterial community on the day of field sampling (DS), $250 \mathrm{~mL}$ of melted snow was filtered through a $0.22 \mu \mathrm{m}$ Whatman nitrocellulose filter (Merck, Darmstadt, Germany) using a sterile filtration unit (Nalgene Nunc International Corporation) and frozen at $-20^{\circ} \mathrm{C}$. To avoid freezing the samples and the associated potential cell death [61, 62], and because temperature was a constant factor in the microcosms, all materials were stored at $4^{\circ} \mathrm{C}$ after field sampling (DS) and for 100 days until the beginning of the experiments, and were maintained at $4^{\circ} \mathrm{C}$ during the experiments.

\section{Microcosm construction}

Prior to constructing the microcosms, a control soil sample was frozen at $-20^{\circ} \mathrm{C}$ and $250 \mathrm{~mL}$ of melted snow was filtered for DNA extraction, referred to as day-10 (D-10). Microcosms were constructed aseptically in a class II biological safety cabinet (ESCO) by adding $30 \mathrm{~g}$ of sieved soil in sterile $50 \mathrm{~mL}$ falcon tubes, packed at a density of approximately $0.96 \mathrm{~g} / \mathrm{cm}^{3}$, within the range of expected density relating to the soil organic carbon in Arctic soils [63]. Microcosms were left for 10 days to allow the soil bacterial communities acclimatise and adapt to the environmental conditions until the start of the experiment (D0). A multichannel peristaltic dosing pump (Jebao DP-4, DP-5 and DP-3S) was used for the delivery of melted snow and sterile water into each microcosm. At the bottom of each tube, an evacuation hole was created using a sterile needle to let the excess liquid exit the system and avoid complete water saturation of the microcosm. A $0.45 \mu \mathrm{m}$ Durapore membrane filter (Merck) was fitted at the bottom of the tube to let the water and microorganisms pass while stopping the soil from leaving the microcosm. The outflow, referred to as flow-through (FT), was collected in a sterile container, replaced on each sampling day [Fig. 1]. Triplicates of each experiment were run in parallel for a total of 12 microcosms per experiment. Soil samples were collected aseptically from the top of the column using sterile spatulas on day 0 (D0, first day of the experiment), day 5 (D5), day 9 (D9), day 14 (D14, last day of melted snow input), day 20 (D20) and day 29 (D29). The collected soil was frozen at $-20^{\circ} \mathrm{C}$ until further processing. On each sampling day, $250 \mathrm{~mL}$ of melted snow was filtered and frozen at $-20^{\circ} \mathrm{C}$ until further processing. The sterile water used in the controls consisted of filtered MilliQ water added to a clean and empty autoclaved container and autoclaved again. The sterility of the water was assessed on each sampling day by microscopy using PetroffHausser chambers and DNA extractions (Supplementary methods). The flow-through output was filtered through a $0.22 \mu \mathrm{m}$ nitrocellulose filter (Merck) on D5, D9 and D14, and frozen at $-20^{\circ} \mathrm{C}$ until further processing.

On each sampling day, the $\mathrm{pH}$ of input snow/water and soil columns was measured using a $5 \mathrm{~mL}$ of snow/water or a 1:5 soil to water ratio and a MettlerToledo FE20 pH meter (Mettler-Toledo Instruments Co., Shanghai, China). The input snow pH (6.33 \pm 0.15$)$ and sterile water pH (5.82 \pm 0.36$)$ were 
acidoneutral. Overall, each microcosm remained within the pH category assigned throughout the duration of the experiments [Fig. S1].

\subsection{Snowmelt rate experiments}

In the Arctic, snow melts at an average rate of $9 \mathrm{~mm}$ water equivalent (we) per day $[25,59,60,64]$. In Svalbard, in cases of extremely rapid melt, rates up to $68 \mathrm{~mm}$ we/day have been recorded (summarised in Winther et al. [59]). The average flow rate ( $9 \mathrm{~mm}$ we/day) was equivalent to $6.4 \mathrm{~mL} /$ day for a $50 \mathrm{~mL}$ falcon tube, which formed the basis of the microcosms, while the fast rate of $68 \mathrm{~mm}$ we/day was equivalent to $48.0 \mathrm{~mL} /$ day. At the fast rate, pilot experiments demonstrated the rapid saturation of the system, preventing the percolation of water through the soil. To simulate a fast melt rate at which the input water would saturate and percolate, a melting rate of $35 \mathrm{~mm}$ we/day was selected, equivalent to $24.7 \mathrm{~mL} / \mathrm{day}$ for a falcon tube. A volume of $6.4 \mathrm{~mL}$ was introduced once a day for average rates and a volume of $6.2 \mathrm{~mL}$ was introduced 4 times a day, every three hours (for 10 hours) for the fast rate. Triplicates of each experiment were run as follows: average rates with melted snow (treatment 1), average rates with sterile water (control 1 ), fast rates with melted snow (treatment 2) and fast rates with sterile water (control 2).

\subsection{Soil pH experiments}

On the day of microcosm set-up (D-10), the $\mathrm{pH}$ of the already acidoneutral soil (Table S1) was adjusted to cover acidic and alkaline $\mathrm{pH}$ ranges. $0.35 \mathrm{~g}$ of Aluminium sulphate $\left(\mathrm{Al}_{2}\left(\mathrm{SO}_{4}\right)_{3}\right)$ was added to decrease soil $\mathrm{pH}$ and $0.44 \mathrm{~g}$ of calcium carbonate $\left(\mathrm{CaCO}_{3}\right)$ was added to increase soil $\mathrm{pH}$. The optimum mass of each chemical to add to the soil was tested in a pilot experiment and in accordance with Nicol et al. [65]. A total of 12 microcosms were prepared, 6 acidic with $\mathrm{pH}=3.65 \pm 0.14$ and 6 alkaline with $\mathrm{pH}=7.97 \pm 0.22$ and left for 10 days at $4^{\circ} \mathrm{C}$ to let the soil bacterial communities acclimatise and adapt to the new environmental conditions. Using the average melt rate of $9 \mathrm{~mm}$ we/day, triplicates of each experiment were as follows: acidic soil with melted snow (treatment 1), acidic soil with sterile water (control 1), alkaline soil with melted snow (treatment 2) and alkaline soil with sterile water (control 2 ). The acidoneutral microcosms $(\mathrm{pH}=5.31 \pm 0.17)$ with average melt rate were run in the previous experiment (melt rate) and not repeated. Instead, the results were reused in different settings to compare the experiments.

\section{DNA extraction, amplicon sequencing and bioinformatic processing}

Soil DNA was extracted using the PowerSoil kit (Qiagen, Carlsbad, CA, USA) and following the manufacturers' protocol. Snow and flow-through (FT) DNA was extracted using the PowerWater kit (Qiagen) and following the manufacturers' protocol. Each extract was PCR amplified using the universal primers 515F-806R [66]. Resulting amplicons were cleaned, normalised, pooled, sequenced on the Illumina MiSeq (as described in Malard et al. [17]) and resulting amplicons were processed using the DADA2 pipeline [67]. Forward and reverse read pairs were trimmed and filtered, with forward reads truncated at 230 base pairs (bp) and reverse reads at $200 \mathrm{bp}$, no ambiguous bases allowed, and each read required to have $<2$ expected errors based on their quality scores. Amplicon sequence variants (ASVs) were independently inferred from the forward and reverse reads of each sample using the run-specific error rates. Reads were dereplicated, pairs were merged, and chimeras were removed. Taxonomic assignment was performed against the SILVA v128 database [68, 69] using the implementation of the RDP (ribosomal database project) naive Bayesian classifier. A total of 6715429 ( \pm 30114 reads/samples) were assigned against 20583 ASVs.

\section{16S rRNA qPCR}

Quantitative real-time PCR (qPCR) was performed on a Bio-Rad CFX96 thermal cycler to quantify copy number of the bacterial 16S rRNA gene [70]. PCR reactions were performed using the QuantiNova SYBR Green PCR kit (Qiagen) and 0.3 $\mu \mathrm{M}$ of universal bacterial 16S rRNA gene primers 1369F and 1492R (detailed protocol in Supplementary Methods). The results were normalised by the mass of soil or the volume of snow or FT filtered.

\section{Statistical analysis}

All statistical analyses and visualisations were performed in the R environment using primarily a combination of the vegan [71], phyloseq [72] and ggplot2 [73] packages. The decontam package [74] was used to identify potential contaminants using the prevalence function. The ASV table was also manually curated to discard ASVs present in the kit and MiSeq controls in higher abundance than in other samples, leaving 19081 ASVs. The rarefaction curves saturated, suggesting that we reached the diversity plateau [Fig. S2]. Bacterial richness and diversity indices [75] were calculated in phylosEq. Differences in 16S rRNA gene abundance and alpha diversity between sample type (snow, soil, FT), experiment (melt rate or pH), treatment (sterile water or snow) and sampling day and the interaction of all factors were assessed by a multi-factorial design using ANOVA and Tukey's Honest Significant Difference (HSD) tests with Bonferroni correction.

The ASV table was normalised to the relative abundance and used to evaluate changes in community composition. PERMANOVA were conducted using the adonis function with 999 permutations to identify significant differences in bacterial composition using the Bray-Curtis community dissimilarity and further observed using principal coordinate analysis (PCoA) [76, 77].

To evaluate the colonisation potential, the ASVs identified in the control microcosms and pre-treated soils (day of field sampling (DS), set-up day (D-10) and first day of the experiment (D0)) were discarded from the treated ASV tables. Then, the ASV tables were filtered to keep the ASVs only identified in the snow (541 unique ASVs). Finally, only ASVs identified in the snow and present in the soils after the start of the experiment were conserved to obtain ASV tables of invaders and potential colonists for each experiment, leaving only 16 ASVs as invaders. All other 525 ASVs were either identified only in the FT or snow samples. Invaders included all taxa which were identified in the snow and soil but not detected in the soil prior to the start of the experiment. Potential colonists were invaders that were identified across multiple days throughout the experiments, regardless of whether they were identified in multiple replicates or not. As new members of a community can naturally undergo abundance fluctuations [47, 49, 50], ASVs identified across multiple days and still identified on D29 were considered potentially successful colonists, regardless of whether they had increasing or decreasing relative abundances. 
Differences between the number of invaders, colonist and potentially successful colonists by experiment were tested using ANOVA and Tukey's Honest Significant Difference (HSD) tests with Bonferroni correction.

\section{Results}

\section{The influence of melt rate}

Overall, the differences in gene copy numbers were significant between sample types [Table 1]. Soil and FT samples had significantly more gene copies than snow samples [Table 1, Fig. S3A]. On average, $4.02 \times 10^{1} 16 \mathrm{~S}$ rRNA gene copies were measured per mL of melted snow and significantly changed by sampling day [Table 1, Fig. S3A]. In soils, the number of gene copies per $\mathrm{g}$ of soil decreased during storage but increased again with the start of the experiment and the addition of water. The number of gene copies was higher in the fast flow than in the average flow experiments and the number of gene copies was consistently higher in the controls than in the treated soils [Table 1, Fig. S3A]. On day 29, all samples returned close to the starting number of gene copies (D0), potentially indicating the stabilization of the soil community 15 days after the end of the melt. In the flow-through samples, higher gene copies were observed in the fast flow than in the average flow experiments [Table 1, Fig. S3A]. In contrast with the soil, the number of gene copies in the flow-through were higher in the treated than in the control samples. Although results were not significant, this is consistent with the addition of microorganisms from the melted snow. In all FT samples, the number of gene copies was highest on day 5 and decreased sharply on all other days. This spike on day 5 was expected as it may reflect the removal of unattached microorganisms, dead cells and relic DNA from the soil, evacuated with the addition of water. 
Table 1

Results of the ANOVA tests on gene copy numbers (qPCR), richness and Shannon diversity [75] and results of the adonis tests on Bray-Curtis community dissimilarity [76, 77]. The experiment column refers to either the different melt rate or soil pH microcosms. The sample type column differentiates between snow, soil and flow through (FT). The formula column indicates the parameters used in the models. Type $=$ sample type/Rate $=$ fast or slow $/$ Treatment (treat) $=$ snow or sterile water input $/$ Day $=$ day of sampling. $\mathrm{P}=$ pvalue, asterisk indicates significant differences $($ Sign $) . * \star *, P<0.001 ; * \star, P<0.01 ; *, P<0.05$.

\begin{tabular}{|c|c|c|c|c|c|c|c|c|c|c|c|c|c|c|}
\hline \multirow[b]{2}{*}{ Experiment } & \multirow[b]{2}{*}{$\begin{array}{l}\text { Sample } \\
\text { type }\end{array}$} & \multirow[b]{2}{*}{ Formula } & \multicolumn{3}{|c|}{ Gene copies (qPCR) } & \multicolumn{3}{|c|}{ Richness } & \multicolumn{3}{|c|}{ Shannon } & \multicolumn{3}{|c|}{$\begin{array}{l}\text { Community } \\
\text { composition }\end{array}$} \\
\hline & & & $\mathrm{F}$ & $\mathrm{p}$ & Sign & $\mathrm{F}$ & $\mathrm{p}$ & Sign & $\mathrm{F}$ & $\mathrm{p}$ & Sign & $\mathrm{R}^{2}$ & $\mathrm{p}$ & Sign \\
\hline Melt rate & all & Type & $\begin{array}{l}\mathrm{F}_{2-302}= \\
734\end{array}$ & $\begin{array}{l}2 \times 10^{-} \\
16\end{array}$ & $\star \star *$ & $\begin{array}{l}F_{2-} \\
68= \\
245\end{array}$ & $2 \times 10^{-16}$ & $\star \star \star ~$ & $\begin{array}{l}F_{2-} \\
68= \\
336\end{array}$ & $\begin{array}{l}2 \times 10^{-} \\
16\end{array}$ & $\star \star \star$ & 0.36 & 0.001 & $\star \star \star ~$ \\
\hline Melt rate & snow & Day & $\begin{array}{l}F_{4-9}= \\
15.2\end{array}$ & 0.0005 & $\star \star \star$ & $\begin{array}{l}\mathrm{F}_{4-} \\
5= \\
3.24\end{array}$ & 0.11 & & $\begin{array}{l}\mathrm{F}_{4-} \\
5= \\
0.96\end{array}$ & 0.50 & & 0.55 & 0.004 & 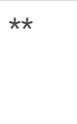 \\
\hline Melt rate & soil & Rate & $\begin{array}{l}\mathrm{F}_{2-160}= \\
24.7\end{array}$ & $\begin{array}{l}4.5 \times 10^{-} \\
10\end{array}$ & $\star \star \star *$ & $\begin{array}{l}F_{3-} \\
39= \\
40\end{array}$ & $\begin{array}{l}5.51 \times 10^{-} \\
12\end{array}$ & 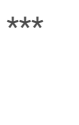 & $\begin{array}{l}\mathrm{F}_{3-} \\
39= \\
36.1\end{array}$ & $\begin{array}{l}2.5 \times 10^{-} \\
11\end{array}$ & 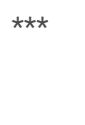 & 0.24 & 0.001 & $\star \star \star ~$ \\
\hline Melt rate & soil & Treat & $\begin{array}{l}\mathrm{F}_{1-160}= \\
18\end{array}$ & $\begin{array}{l}3.7 \times 10^{-} \\
5\end{array}$ & $\star \star \star$ & $\begin{array}{l}\mathrm{F}_{1-} \\
39= \\
2.62\end{array}$ & 0.11 & & $\begin{array}{l}\mathrm{F}_{1-} \\
39= \\
1.83\end{array}$ & 0.18 & & 0.02 & 0.013 & * \\
\hline Melt rate & soil & $\begin{array}{l}\text { Rate* } \\
\text { Treat }\end{array}$ & $\begin{array}{l}\mathrm{F}_{1-160}= \\
3.85\end{array}$ & 0.052 & & $\begin{array}{l}F_{1-} \\
39= \\
0.36\end{array}$ & 0.55 & & $\begin{array}{l}\mathrm{F}_{1-} \\
39= \\
0.81\end{array}$ & 0.37 & & 0.018 & 0.05 & \\
\hline Melt rate & soil & Rate*Day & $\begin{array}{l}\mathrm{F}_{4-} \\
160=3.15\end{array}$ & 0.016 & * & $\begin{array}{l}\mathrm{F}_{4-} \\
39= \\
0.48\end{array}$ & 0.75 & & $\begin{array}{l}\mathrm{F}_{4-} \\
39= \\
0.32\end{array}$ & 0.86 & & 0.06 & 0.10 & \\
\hline Melt rate & soil & $\begin{array}{l}\text { Treat } \\
\text { *Day }\end{array}$ & $\begin{array}{l}\mathrm{F}_{4-} \\
160=1.36\end{array}$ & 0.25 & & $\begin{array}{l}\mathrm{F}_{4-} \\
39= \\
3.25\end{array}$ & 0.02 & * & $\begin{array}{l}\mathrm{F}_{4-} \\
39= \\
1.66\end{array}$ & 0.18 & & 0.05 & 0.58 & \\
\hline Melt rate & soil & $\begin{array}{l}\text { Rate }^{\star} \\
\text { Treat*Day }\end{array}$ & $\begin{array}{l}\mathrm{F}_{4-160}= \\
0.63\end{array}$ & 0.64 & & $\begin{array}{l}F_{4-} \\
39= \\
1.41\end{array}$ & 0.25 & & $\begin{array}{l}\mathrm{F}_{4-} \\
39= \\
0.30\end{array}$ & 0.87 & & 0.04 & 0.69 & \\
\hline Melt rate & $\mathrm{FT}$ & Rate & $\begin{array}{l}F_{1-96}= \\
9.96\end{array}$ & 0.002 & $\star *$ & $\begin{array}{l}F_{1-} \\
24= \\
6.84\end{array}$ & 0.015 & * & $\begin{array}{l}\mathrm{F}_{1-} \\
24= \\
1.06\end{array}$ & 0.32 & & 0.05 & 0.004 & $\star \star$ \\
\hline Melt rate & FT & Treat & $\begin{array}{l}F_{1-96}= \\
1.30\end{array}$ & 0.26 & & $\begin{array}{l}F_{1-} \\
24= \\
2.73\end{array}$ & 0.11 & & $\begin{array}{l}\mathrm{F}_{1-} \\
24= \\
1.62\end{array}$ & 0.22 & & 0.03 & 0.2 & \\
\hline Melt rate & FT & $\begin{array}{l}\text { Rate* } \\
\text { Treat }\end{array}$ & $\begin{array}{l}F_{1-96}= \\
0.32\end{array}$ & 0.57 & & $\begin{array}{l}F_{1-} \\
24= \\
0.09\end{array}$ & 0.77 & & $\begin{array}{l}\mathrm{F}_{1-} \\
24= \\
0.87\end{array}$ & 0.36 & & 0.03 & 0.15 & \\
\hline Melt rate & $\mathrm{FT}$ & Rate*Day & $\begin{array}{l}F_{2-96}= \\
11.1\end{array}$ & $4 \times 10^{-5}$ & $\star \star \star *$ & $\begin{array}{l}\mathrm{F}_{2-} \\
24= \\
17.69\end{array}$ & $10^{-5}$ & $\star \star \star ~$ & $\begin{array}{l}\mathrm{F}_{2-} \\
24= \\
1.97\end{array}$ & 0.16 & & 0.08 & 0.004 & $\star \star$ \\
\hline Melt rate & $\mathrm{FT}$ & Treat*Day & $\begin{array}{l}F_{2-96}= \\
2.02\end{array}$ & 0.14 & & $\begin{array}{l}F_{2-} \\
24= \\
1.60\end{array}$ & 0.22 & & $\begin{array}{l}\mathrm{F}_{2-} \\
24= \\
0.07\end{array}$ & 0.94 & & 0.05 & 0.43 & \\
\hline Melt rate & $\mathrm{FT}$ & $\begin{array}{l}\text { Rate }^{\star} \\
\text { Treat*Day }\end{array}$ & $\begin{array}{l}F_{2-96}= \\
0.91\end{array}$ & 0.41 & & $\begin{array}{l}F_{2-} \\
24= \\
0.42\end{array}$ & 0.66 & & $\begin{array}{l}\mathrm{F}_{2-} \\
24= \\
0.08\end{array}$ & 0.92 & & 0.05 & 0.36 & \\
\hline Soil pH & all & Type & $\begin{array}{l}\mathrm{F}_{2-472}= \\
161\end{array}$ & $\begin{array}{l}2 \times 10^{-} \\
16\end{array}$ & $\star \star \star *$ & $\begin{array}{l}F_{5-} \\
108= \\
22.7\end{array}$ & $5.7 \times 10^{-9}$ & 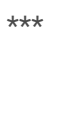 & $\begin{array}{l}\mathrm{F}_{5-} \\
108= \\
240.7\end{array}$ & $\begin{array}{l}2 \times 10^{-} \\
16\end{array}$ & $\star \star \star$ & 0.23 & 0.001 & $\star \star \star$ \\
\hline Soil pH & snow & Day & $\begin{array}{l}F_{4-8}= \\
25.3\end{array}$ & 0.0001 & $\star * *$ & $\begin{array}{l}F_{4-} \\
5= \\
0.86\end{array}$ & 0.55 & & $\begin{array}{l}\mathrm{F}_{4-} \\
5= \\
0.55\end{array}$ & 0.71 & & 0.48 & 0.1 & \\
\hline
\end{tabular}




\begin{tabular}{|c|c|c|c|c|c|c|c|c|c|c|c|c|c|c|}
\hline \multirow[b]{2}{*}{ Soil pH } & \multirow[b]{2}{*}{ soil } & \multirow[b]{2}{*}{$\mathrm{pH}$} & \multicolumn{3}{|c|}{ Gene copies (qPCR) } & \multicolumn{3}{|c|}{ Richness } & \multicolumn{3}{|c|}{ Shannon } & \multicolumn{3}{|c|}{$\begin{array}{l}\text { Community } \\
\text { composition }\end{array}$} \\
\hline & & & $\begin{array}{l}\mathrm{F}_{3-262}= \\
192\end{array}$ & $\begin{array}{l}2 \times 10^{-} \\
16\end{array}$ & $\star \star \star$ & $\begin{array}{l}\mathrm{F}_{3-} \\
68= \\
36.1\end{array}$ & $\begin{array}{l}4.6 \times 10^{-} \\
14\end{array}$ & $\star * \star$ & $\begin{array}{l}\mathrm{F}_{3-} \\
68= \\
32.3\end{array}$ & $\begin{array}{l}4.4 \times 10^{-} \\
13\end{array}$ & $\star \star \star$ & 0.36 & 0.001 & 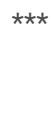 \\
\hline Soil pH & soil & Treat & $\begin{array}{l}\mathrm{F}_{1-262}= \\
0.78\end{array}$ & 0.38 & & $\begin{array}{l}\mathrm{F}_{1-} \\
68= \\
10.03\end{array}$ & 0.002 & ** & $\begin{array}{l}\mathrm{F}_{1-} \\
68= \\
7.90\end{array}$ & 0.006 & ** & 0.01 & 0.01 & * \\
\hline Soil pH & soil & $\mathrm{pH}^{\star}$ Treat & $\begin{array}{l}\mathrm{F}_{2-262}= \\
0.37\end{array}$ & 0.69 & & $\begin{array}{l}\mathrm{F}_{2-} \\
68= \\
8.54\end{array}$ & 0.0005 & $\star \star \star ~$ & $\begin{array}{l}\mathrm{F}_{2-} \\
68= \\
8.25\end{array}$ & 0.0006 & $\star \star \star *$ & 0.03 & 0.004 & $\star \star$ \\
\hline Soil pH & soil & $\mathrm{pH}^{\star}$ Day & $\begin{array}{l}\mathrm{F}_{10-} \\
262= \\
3.40\end{array}$ & 0.0003 & $\star \star \star ~$ & $\begin{array}{l}F_{9-} \\
68= \\
6.58\end{array}$ & ${ }_{6}^{1.08 \times 10^{-}}$ & $\star \star \star$ & $\begin{array}{l}\mathrm{F}_{9-} \\
68= \\
4.16\end{array}$ & 0.0003 & $\star \star \star ~$ & 0.1 & 0.001 & $\star \star \star *$ \\
\hline Soil pH & soil & Treat*Day & $\begin{array}{l}F_{5-262}= \\
1.90\end{array}$ & 0.095 & & $\begin{array}{l}\mathrm{F}_{5-} \\
68= \\
2.36\end{array}$ & 0.049 & * & $\begin{array}{l}\mathrm{F}_{5-} \\
68= \\
1.04\end{array}$ & 0.40 & & 0.03 & 0.38 & \\
\hline Soil pH & soil & $\begin{array}{l}\mathrm{pH}^{\star} \\
\text { Treat*Day }\end{array}$ & $\begin{array}{l}\mathrm{F}_{10-} \\
262= \\
2.27\end{array}$ & 0.015 & * & $\begin{array}{l}F_{9-} \\
68= \\
0.98\end{array}$ & 0.46 & & $\begin{array}{l}F_{9-} \\
68= \\
0.68\end{array}$ & 0.73 & & 0.04 & 0.83 & \\
\hline Soil pH & $\mathrm{FT}$ & $\mathrm{pH}$ & $\begin{array}{l}\mathrm{F}_{2-144}= \\
7.60\end{array}$ & 0.0007 & $\star \star \star$ & $\begin{array}{l}\mathrm{F}_{2-} \\
35= \\
1.98\end{array}$ & 0.15 & & $\begin{array}{l}\mathrm{F}_{2-} \\
35= \\
1.73\end{array}$ & 0.19 & & 0.09 & 0.001 & $\star \star \star *$ \\
\hline Soil pH & FT & Treat & $\begin{array}{l}\mathrm{F}_{2-144}= \\
0.41\end{array}$ & 0.52 & & $\begin{array}{l}\mathrm{F}_{1-} \\
35= \\
3.34\end{array}$ & 0.08 & & $\begin{array}{l}\mathrm{F}_{1-} \\
35= \\
3.34\end{array}$ & 0.08 & & 0.02 & 0.22 & \\
\hline Soil pH & $\mathrm{FT}$ & $\mathrm{pH}^{\star}$ Treat & $\begin{array}{l}\mathrm{F}_{2-144}= \\
0.37\end{array}$ & 0.70 & & $\begin{array}{l}\mathrm{F}_{2-} \\
35= \\
0.20\end{array}$ & 0.82 & & $\begin{array}{l}\mathrm{F}_{2-} \\
35= \\
0.20\end{array}$ & 0.82 & & 0.04 & 0.25 & \\
\hline Soil pH & $\mathrm{FT}$ & $\mathrm{pH}^{\star}$ Day & $\begin{array}{l}\mathrm{F}_{4-144}= \\
7.63\end{array}$ & $10^{-5}$ & $\star \star \star$ & $\begin{array}{l}\mathrm{F}_{4-} \\
35= \\
1.91\end{array}$ & 0.13 & & $\begin{array}{l}\mathrm{F}_{4-} \\
35= \\
1.91\end{array}$ & 0.13 & & 0.08 & 0.03 & * \\
\hline Soil pH & $\mathrm{FT}$ & Treat*Day & $\begin{array}{l}\mathrm{F}_{2-144}= \\
0.44\end{array}$ & 0.64 & & $\begin{array}{l}\mathrm{F}_{2-} \\
35= \\
4.57\end{array}$ & 0.02 & * & $\begin{array}{l}\mathrm{F}_{2-} \\
35= \\
4.57\end{array}$ & 0.02 & * & 0.04 & 0.16 & \\
\hline Soil pH & $\mathrm{FT}$ & $\begin{array}{l}\mathrm{pH}^{\star} \\
\text { Treat*Day }\end{array}$ & $\begin{array}{l}\mathrm{F}_{4-144}= \\
0.35\end{array}$ & 0.84 & & $\begin{array}{l}\mathrm{F}_{4-} \\
35= \\
5.12\end{array}$ & 0.002 & $\star \star$ & $\begin{array}{l}\mathrm{F}_{4-} \\
35= \\
5.12\end{array}$ & 0.002 & $\star \star$ & 0.08 & 0.12 & \\
\hline
\end{tabular}

Differences in alpha diversity were significant by sample type [Fig. 2A and B, Table 1]. In the snow, differences from the day of field sampling until the end of the experiments were not significant [Fig. 2A and B, Table 1]. In the soils, as with gene copies, there was a decrease in alpha diversity measures with storage (pre-treated), which increased at the beginning of the experiment with the addition of water [Fig. 2A and B, Table 1]. Alpha diversity was significantly higher in the average flow rate. However, there was no significant difference between control and treated samples and the day of sampling had limited influence on soil alpha diversity measures [Fig. 2A and B, Table 1]. In the flow-through, the number of ASVs was significantly higher in the fast flow experiments but decreased with time, highlighting the spike at D5, also observed with gene copy numbers [Fig. 2A and B, Table 1].

Overall, differences in bacterial community composition by sample type were observed using the Bray-Curtis dissimilarity and PCoA [Fig. 3A, Table 1]. Snow communities changed significantly between the day of field sampling and the end of the experiment [Table 1] and were primarily composed of Proteobacteria, Actinobacteria and Bacteroidetes [Fig. 3B]. Large variations in the composition of FT samples masked the potential variation in soil samples [Fig. 3A] and therefore, the PCoA of soil communities was assessed separately [Fig. S4]. The soil community on the day of field sampling changed with storage [Fig. 3A, Fig. S4]. Soil communities clustered separately between flow rates, but as for alpha diversity, controls and treated samples were similar [Table 1, Fig. S4]. Soil communities were primarily composed of Acidobacteria, Actinobacteria, Bacteroidetes, Chloroflexi, Gemmatimonadetes, Planctomycetes, Proteobacteria and Verrucomicrobia [Fig. 3B]. The communities identified in the flow through presented clear variations, primarily separated by flow rate and sampling day [Fig. 3A]. All FT samples were dominated by Proteobacteria but differences in communities with flow rate were observed. For instance, all fast FT samples had large proportions of Acidobacteria and Bacteroidetes while in the average rate, communities significantly changed on D14 with the depletion of Acidobacteria [Fig. 3B].

\section{The influence of soil pH}


Here, we assessed the influence of soil pH on the colonisation potential of snow microorganisms. The results from the average flow rate were used as the acidoneutral samples for comparison. As in the melt rate experiments, the differences in gene copy numbers were significant between sample types, with soil and FT samples harbouring significantly more gene copies than snow samples, which changed significantly by sampling day [Table 1, Fig. S3B]. In soils, the number of gene copies decreased during storage between the day of field sampling (DS) and D-10. After pH manipulation (D-10) and until D0, the number of gene copies increased in alkaline soils but decreased in acidic soils. During the experiment, the gene copy number remained lowest in acidic and highest in alkaline soils with no significant differences between controls and treated soils [Table 1, Fig. S3B]. In the flow-through, higher gene copies were quantified in the alkaline soils, which also presented the highest variability [Fig. S3B, Table 1]. As observed in the melt rate experiments, the number of gene copies peaked on D5 and decreased with time.

Differences in alpha diversity were significant by sample type [Fig. $2 \mathrm{C}$ and D, Table 1]. In the snow, alpha diversity did not change significantly from the day of sampling until the end of the experiments [Fig. 2C and D, Table 1]. In the soils, as with gene copies, there was a decrease in alpha diversity measures with storage (pre-treated). However, alpha diversity changed following pH manipulation showing an increase in alkaline soils and a decrease in acidic soils [Fig. 2A and B]. During the experiment, both soil pH and snow/water treatment were identified as significant variables influenced by the day of sampling [Table 1]. Interestingly, on day 29, all microcosms harboured similar alpha diversity levels, except the alkaline controls [Fig. 2C and D], suggesting stabilisation of the communities. In the flow-through, alpha diversity decreased with time and the interactions between soil pH, treatment and sampling day were significant [Fig. 2C and D, Table 1].

Overall, differences in bacterial community composition by sample type were observed [Fig. 3C, Table 1]. In the PCoA, the snow samples clustered closely together, indicating similar communities over time dominated by Proteobacteria and Firmicutes [Fig. 3C, Table 1]. Acidic, acidoneutral and alkaline soil samples all formed different clusters indicating strong differences in community composition [Fig. 3C]. The horseshoe effect observed in the PCoA reflects the $\mathrm{pH}$ gradient and highlights the change in community composition across this gradient [78]. This difference in soil community composition was further observed in Fig. 3D, illustrating the community composition at the phylum level. We observed a shift in community composition during storage but also after pH manipulation, between D-10 and D0. Acidic communities presented an increase in Acidobacteria and Proteobacteria while an even stronger increase in Proteobacteria was observed in alkaline communities. The addition of water after the start of the experiments further enhanced this increase in Proteobacteria [Fig. 3D]. Acidic soil communities were dominated by Acidobacteria and Proteobacteria until it shifted again at D14 and was characterised by the increase in Actinobacteria, Chloroflexi, Gemmatimonadetes and Verrucomicrobia. Alkaline soil communities were dominated by Proteobacteria and presented a decrease in Proteobacteria along with an increase in Chloroflexi and Verrucomicrobia after D14 [Fig. 3D]. The shift on D14 might reflect the adaptation of the community to the environmental conditions, followed by the stabilisation after the melt. Flow through samples also presented some clear differences with pH [Fig. 3C and D, Table 1]. Acidic FT were dominated by Actinobacteria, Chloroflexi and Verrucomicrobia, while Proteobacteria and Verrucomicrobia dominated alkaline FT. In comparison, Verrucomicrobia were almost absent from the acidoneutral FT.

\section{Colonisation potential}

To assess whether colonisation of the soil by microorganisms in the snow occurred, only the ASVs identified in the snow, absent from the controls and pretreated soils (DS, D-10 and D0) but identified in the soils from D5 were selected for further analysis. Only 16 ASVs fulfilled these conditions and were considered potential invaders. All were classified as Proteobacteria or Bacteroidetes, primarily Alphaproteobacteria, Betaproteobacteria, Flavobacteriia and Sphingobacteriia at the class level [Fig. 4 and Table S2]. In some cases, we identified taxa on D20 or D29 that were not previously identified and appeared new. It is likely that these taxa were previously present but had abundances below the detection threshold.

In the fast flow experiments, a total of 13 ASVs were identified as invaders depositing in the soils [Fig. 4A and table S2]. Of these 13 invaders, 7 were identified across multiple days and were considered potential colonists. However, only 2 persisted until D29 suggesting potentially successful colonists. In the average flow experiments (acidoneutral experiments), 9 ASVs were identified as invaders [Fig. 4B and table S2]. Of these 9 ASVs, 8 were identified across multiple days and considered potential colonists. 5 ASVs persisted until D29 and were considered potentially successful colonists. Differences in invaders, colonists and potentially successful colonists were not statistically significant between flow rates. In acidic soils, only 5 ASVs were identified as invaders [Fig. 4C and table S2]. Of these 5 invaders, 4 were identified across multiple days and considered potential colonists; however, only two persisted until D29. In alkaline soils, 9 ASVs were identified as invaders [Fig. 4D]. Of these 9 invaders, 7 were identified across multiple days and considered potential colonists but only 1 persisted until D29. Overall, the persistence of taxa until the end of the experiment was highest at the average flow in acidoneutral soils, with 5 potentially successful colonisation events. The higher flow rate increased the number of invaders but the persistence across time decreased. In acidic soils at the average flow rate, the number of invaders and persistence with time was much lower. In alkaline soils, the number of invaders was equal to that observed in acidoneutral soils but persistence with time was strongly reduced. Statistically, the number of invaders and colonists was significantly higher in acidoneutral soils (ANOVA, $p=0.02$ and $p=0.009$ respectively), and potentially successful colonists were only marginally more successful (ANOVA, $p=$ 0.056).

\section{Discussion}

In this study, we assessed the influence of increased precipitation (via the melt rate) and soil pH on the colonisation potential of snow microorganisms. Overall, we rejected the first hypothesis that increased precipitation (higher flow rate) would promote successful colonisations due to the higher inoculum density as well as increased ecosystem disturbance. However, we did confirm the second hypothesis by observing increased colonisation in acidoneutral soils compared to acidic and alkaline soils.

In both sets of experiments, the number of gene copies was consistently higher in the control than in the treated soils. This may be a signal of invasion, that is, species in the controls were not experiencing interactions with outside invaders, did not have to partition resources and could therefore grow to higher 
abundances. This signal of invasion was further observed for the richness and diversity, consistently higher in the treated soils, in line with the addition of snow microorganisms.

The fast flow rate increased the input of microorganisms in the system, as would be expected from increased precipitation, and was expected to cause greater disturbance than the average melt rate. Ecosystem disturbance is considered a key factor for successful colonisation by newly deposited microbial invaders, with increasing disturbance enhancing the chances of successful colonisation [44, 45]. We expected the addition of water at the higher rate to disturb soil communities (observed via changes in alpha and beta diversity) and increase the colonisation potential. Instead, the strongest impact on communities was observed at the average rate. Richness and diversity increased, and the soil community composition shifted away from the composition on the first day of the experiment [Fig. S4]. Furthermore, melted snow has been shown to add nutrients to the ecosystem, resulting in a nutrient pulse of carbon, nitrogen and phosphorus [26, 39, 40,79]. As nutrient pulses increase the chances of successful colonisation [41, 80, 81], we expected to observe differences between the controls and treated samples. Instead, controls and treated soils within each experiment remained similar and only differences between experiments (average and fast rates) were observed. The shift in communities between average and fast flow rate suggest physical selection of microorganisms. For instance, fast growing r-strategists or EPS (extracellular polymeric substances) producing bacteria might be selected in the fast flow microcosms to ensure attachment, aggregation and growth in the soil system [82, 83]. Overall, following the increased input of microorganisms, we observed more invaders but low persistence with time and only two potentially successful colonists. At the average rate, the number of invaders was lower but persistence with time was increased and five potentially successful colonists were identified, suggesting that a slower rate may give more time for microorganisms to colonise the ecosystem instead of being pushed out of the system by a higher flow rate.

As pH has previously been identified as a key driver of bacterial community structure in global [14, 16] and in Arctic soils [17], and dispersal is an important process structuring bacterial communities, the influence of soil pH on the colonisation success was investigated. The soil pH appeared to have a stronger influence on soil bacterial communities than flow rate. Not only were richness and diversity lower than in acidoneutral soils, but community composition was clearly different, forming 3 distinct clusters in the PCoA. Contrary to the flow rate experiments, communities between control and treated soils were also different, showing that the input of snow or sterile water had different consequences, potentially due to the input of nutrients from the snow and the different bacterial communities in acidic and alkaline soils. Acidic soils contained the lowest number of invaders deposited, as only two were considered potentially successful colonists. In alkaline soils, as in acidoneutral soils, an equal number of invaders were identified. However, persistence with time was much lower and only one potentially successful colonist was identified. The low colonisation observed in acidic and alkaline samples and successful colonisation in acidoneutral soils confirms the second hypothesis that acidoneutral soils would promote successful colonisations. Furthermore, it suggests that while the flow rate is an important parameter in promoting successful colonisation, soil pH may be an even more important factor limiting colonisation.

While stochasticity should be considered, all potentially successful colonists were identified in multiple replicates across different time points within each experiment, as well as in different experiments [Fig. 4, table S2]. For instance, ASV3 is a colonist at both flow rates, ASV1 and 4 are colonists of both acidoneutral and acidic soils while ASV6 colonised acidoneutral and alkaline soils. Therefore, these colonisations are unlikely to be the result of random events. Overall, the same taxa were repeatedly deposited in soils, suggesting active and selective colonisation of the soil by these taxa. The potentially successful colonists (Proteobacteria and Bacteroidetes) were primarily classified as r-strategists (as in Fierer et al. [84] and Ho et al. [82]), with high growth rates and generally considered more likely to successfully colonise [85, 86].

The colonisation and persistence with time observed in acidoneutral soils was in agreement with the consensus that acidoneutral soils may decrease the adaptative pressure on microbial communities [87, 88]. Arctic acidoneutral soils harbour more generalist taxa [17], generally considered more prone to dispersal [89-91]. Therefore, the higher successful colonisation of acidoneutral soils further supported the role of dispersal in shaping bacterial communities in these ecosystems.

On the other hand, the lower number of invading taxa in acidic soils was not surprising considering that most bacterial taxa decrease in abundance with decreasing $\mathrm{pH}[55,92]$, including the invading taxa Bacteroidetes. Potentially successful colonists of acidic and alkaline soils colonised acidoneutral soils, however, they did not colonise each other. The low rate of colonisation of acidic and alkaline soils, both generally characterised as harsh [14, 92], may highlight the need for effective adaptations $[93,94]$ lacking in the deposited microorganisms. They may also be worse competitors than the indigenous soil communities, generally dominated by specialist taxa [17] and acclimated to the soil pH. However, in this study, we opted to use the same soil bacterial community as a baseline to evaluate the colonisation potential. Therefore, we manipulated the soil pH by the addition of aluminium sulphate and calcium carbonate [65]. While we let the communities acclimatise to the new soil pH, they may be less adapted than indigenous communities in naturally acidic and alkaline soils. The addition of sulphate coupled with the addition of water could have formed sulphuric acid, especially at lower flow rates where the soil was exposed to air. Toxic metals such as manganese, aluminium and arsenic may have been released [95, 96]. On the other hand, calcium carbonate is used to increase soil pH and reduce the possible toxicity of manganese and aluminium ions [96-98]. In all manipulated pH microcosms, we observed a shift in bacterial communities following these adjustments (between D-10 and D0). Future studies could repeat these experiments using soils within the targeted $\mathrm{pH}$ range and the associated indigenous communities to establish if the colonisation potential is also lower in these natural systems. It is also interesting to note that the snow pH was acidoneutral $(6.33 \pm 0.15)$ and therefore, snow microorganisms may have already been well adapted for acidoneutral soil conditions. As snow pH is generally acidoneutral [99-104], this scenario is rather realistic. However, we cannot exclude the possibility that acidic or alkaline precipitations may promote colonisation in soils within the same $\mathrm{pH}$ range.

Overall, local environmental conditions may be more important determinant factors influencing the outcome of colonisation than increased precipitation or faster melt events. Furthermore, we did not observe the inverse relationship between microbial diversity and invasion outcome previously identified or theorised $[18,19,49,105]$. Here, more colonisations were observed in the most rich and diverse communities (acidoneutral soils), suggesting that the innate diversity of indigenous soil communities may not prevent outside colonisations. Instead, only invaders presenting the right adaptations to colonise a free

Page $9 / 17$ 
niche or outcompete indigenous microorganisms may be able to successfully colonise in the medium to long term. Following the deposition, the invaders have to adapt, compete for resources and then grow and spread in the ecosystem to colonise [18, 19]. Here, we demonstrated that microorganisms were successfully deposited but only few taxa had the potential to successfully colonise the soils. After 15 days, the majority had disappeared leading to likely failed colonisations; however, even failed colonisations may influence indigenous microbial communities [50].

\section{Conclusions}

This study used the Arctic snowpack as a model system to investigate microbial colonisation of snow bacteria deposited into Arctic soils. First, we tested the impact of increased precipitation (inoculum density) and the subsequent faster snowmelt rate (ecosystem disturbance) on the colonisation outcome. We identified more invaders but decreased persistence with time and a lower number of successful colonisation events. We also evaluated the influence on soil pH on this colonisation potential. Here, persistence with time decreased and a lower number of successful colonisation events were recorded in acidic and alkaline soils compared with acidoneutral soils. Overall, we demonstrated that soil bacterial communities could change significantly with snowmelt and that microorganisms were successfully deposited in soils following snowmelt events. However, we showed that only few taxa successfully colonised and established in these soil communities. Results suggest that local soil properties might have a greater influence on the colonisation outcome than increased precipitation or ecosystem disturbance.

\section{Declarations}

\section{Ethics approval}

Not applicable

\section{Consent for publication}

Not applicable

\section{Availability of data and materials}

The dataset is deposited at the European Nucleotide Archive under the BioProject accession PRJNA564428.

\section{Competing interests}

The authors declare that they have no competing interests

\section{Funding}

This work was supported by a grant from the European Commission's Marie Sklowdowska Curie Actions program under project number 675546.

\section{Authors' contributions}

LAM and DAP conceived and designed the study, LAM carried the experimental work, laboratory work, bioinformatics processing and statistical analysis. LAM drafted the manuscript and DAP revised and approved the final version.

\section{Acknowledgements}

The authors thank Lewis Cuthbertson and Khadija Jabeen for the occasional care of the experiment. MiSeq sequencing of the 16S rRNA gene was performed by the NU-OMICS sequencing service (Northumbria University).

\section{References}

1. Smets W, Moretti S, Denys S, Lebeer S. Airborne bacteria in the atmosphere: presence, purpose, and potential. Atmos Environ. 2016;139:214-21.

2. Smith DJ, Timonen HJ, Jaffe DA, Griffin DW, Birmele MN, Perry KD, Ward PD, Roberts MSJAEM. Intercontinental dispersal of bacteria and archaea by transpacific winds. 2013, 79(4):1134-1139.

3. Barberán A, Henley J, Fierer N, Casamayor EOJSotTE. Structure, inter-annual recurrence, and global-scale connectivity of airborne microbial communities. 2014, 487:187-195.

4. Barberán A, Ladau J, Leff JW, Pollard KS, Menninger HL, Dunn RR. Fierer NJPotNAoS: Continental-scale distributions of dust-associated bacteria and fungi. 2015, 112(18):5756-5761.

5. Maki T, Lee KC, Kawai K, Onishi K, Hong CS, Kurosaki Y, Shinoda M, Kai K, Iwasaka Y. Archer SDJJoGRA: Aeolian dispersal of bacteria associated with desert dust and anthropogenic particles over continental and oceanic surfaces. 2019, 124(10):5579-5588.

6. Harding T, Jungblut AD, Lovejoy C, Vincent WF. Microbes in High Arctic snow and implications for the cold biosphere. Appl Environ Microbiol. 2011;77(10):3234-43.

7. Cuthbertson L, Amores-Arrocha H, Malard LA, Els N, Sattler B, Pearce DA. Characterisation of Arctic Bacterial Communities in the Air above Svalbard. Biology. 2017;6(2):29. 
8. Šantl-Temkiv T, Gosewinkel U, Starnawski P, Lever M, Finster K. Aeolian dispersal of bacteria in southwest Greenland: their sources, abundance, diversity and physiological states. FEMS Microbiol Ecol. 2018;94(4):fiy031.

9. Pearce DA, Bridge PD, Hughes KA, Sattler B, Psenner R, Russell NJ. Microorganisms in the atmosphere over Antarctica. FEMS Microbiol Ecol. 2009;69(2):143-57.

10. Pearce DA, Hughes K, Lachlan-Cope T, Harangozo S, Jones AE. Biodiversity of air-borne microorganisms at Halley station, Antarctica. Extremophiles. 2010;14(2):145-59.

11. Bottos EM, Woo AC, Zawar-Reza P, Pointing SB, Cary SC. Airborne bacterial populations above desert soils of the McMurdo Dry Valleys, Antarctica. Microbial ecology. 2014;67(1):120-8.

12. Archer SD, Lee KC, Caruso T, Maki T, Lee CK, Cary SC, Cowan DA, Maestre FT. Pointing SBJNm: Airborne microbial transport limitation to isolated Antarctic soil habitats. 2019, 4(6):925-932.

13. De Wit R, Bouvier T. 'Everything is everywhere, but, the environment selects'; what did Baas Becking and Beijerinck really say? Environmental microbiology 2006, 8(4):755-758.

14. Fierer N, Jackson RB. The diversity and biogeography of soil bacterial communities. Proc Natl Acad Sci USA. 2006;103(3):626-31.

15. Bahram M, Hildebrand F, Forslund SK, Anderson JL, Soudzilovskaia NA, Bodegom PM, Bengtsson-Palme J, Anslan S, Coelho LP, Harend H. Structure and function of the global topsoil microbiome. Nature. 2018;560(7717):233-7.

16. Delgado-Baquerizo M, Oliverio AM, Brewer TE, Benavent-González A, Eldridge DJ, Bardgett RD, Maestre FT, Singh BK, Fierer N. A global atlas of the dominant bacteria found in soil. Science. 2018;359(6373):320-5.

17. Malard LA, Anwar MZ, Jacobsen CS, Pearce DA. Biogeographical patterns in soil bacterial communities across the Arctic region. FEMS microbiology ecology 2019, 95(9).

18. Mallon CA, Van Elsas JD, Salles JFJTim. Microbial invasions: the process, patterns, and mechanisms. 2015, 23(11):719-729.

19. Kinnunen M, Dechesne A, Proctor C, Hammes F, Johnson D, Quintela-Baluja M, Graham D, Daffonchio D, Fodelianakis S. Hahn NJTlj: A conceptual framework for invasion in microbial communities. 2016, 10(12):2773-2779.

20. Reche I, D'Orta G, Mladenov N, Winget DM, Suttle CAJTlj. Deposition rates of viruses and bacteria above the atmospheric boundary layer. 2018, 12(4):1154-1162.

21. Peter H, Hörtnagl P, Reche I, Sommaruga RJEmr. Bacterial diversity and composition during rain events with and without S aharan dust influence reaching a high mountain lake in the A Ips. 2014, 6(6):618-624.

22. Weil T, De Filippo C, Albanese D, Donati C, Pindo M, Pavarini L, Carotenuto F, Pasqui M, Poto L, Gabrieli JJM. Legal immigrants: invasion of alien microbial communities during winter occurring desert dust storms. 2017, 5(1):32.

23. Fløistrup KM, Olsen MN, Rasmussen TG, Ekelund F, Altenburger AJASE. Recruitment of airborne microorganisms on sterilized soil at different heights above ground. 2018, 126:85-87.

24. Evans S, Bell-Dereske L, Dougherty K, Kittredge HJEm: Dispersal alters soil microbial community response to drought. 2019.

25. Winther J-G, Bruland O, Sand K, Gerland S, Marechal D, Ivanov B, Gøowacki P. König MJPr: Snow research in Svalbard-an overview. 2003, 22(2):125144.

26. Larose C, Dommergue A, Vogel TM. The dynamic arctic snow pack: an unexplored environment for microbial diversity and activity. Biology. 2013;2(1):317-30.

27. Malard LA, Šabacká M, Magiopoulos I, Mowlem M, Hodson A, Tranter M, Siegert MJ, Pearce DAJFiM. Spatial variability of Antarctic surface snow bacterial communities. 2019, 10:461.

28. Els N, Larose C, Baumann-Stanzer K, Tignat-Perrier R, Keuschnig C, Vogel TM, Sattler B. Microbial composition in seasonal time series of free tropospheric air and precipitation reveals community separation. Aerobiologia. 2019;35(4):671-701.

29. Russell NJPTotRSoLB B. Sciences: Cold adaptation of microorganisms. 1990, 326(1237):595-611.

30. Margesin R, Miteva VJRim. Diversity and ecology of psychrophilic microorganisms. 2011, 162(3):346-361.

31. Maccario L, Sanguino L, Vogel TM. Larose CJRim: Snow and ice ecosystems: not so extreme. 2015, 166(10):782-795.

32. Gray D, Toth B, Zhao L, Pomeroy J, Granger RJHP. Estimating areal snowmelt infiltration into frozen soils. 2001, 15(16):3095-3111.

33. Iwata Y, Hayashi M, Hirota TJVZJ. Comparison of snowmelt infiltration under different soil-freezing conditions influenced by snow cover. 2008, 7(1):79-86.

34. Amato P, Hennebelle R, Magand O, Sancelme M, Delort A-M, Barbante C, Boutron C, Ferrari CJFmE: Bacterial characterization of the snow cover at Spitzberg, Svalbard. 2007, 59(2):255-264.

35. Zhang S, Yang G, Wang Y, Hou SJJoES. Abundance and community of snow bacteria from three glaciers in the Tibetan Plateau. 2010, 22(9):14181424.

36. Cameron KA, Hagedorn B, Dieser M, Christner BC, Choquette K, Sletten R, Crump B, Kellogg C, Junge K. Diversity and potential sources of microbiota associated with snow on western portions of the Greenland Ice Sheet. Environ Microbiol. 2015;17(3):594-609.

37. Hauptmann AL, Stibal M, Bælum J, Sicheritz-Pontén T, Brunak S, Bowman JS, Hansen LH, Jacobsen CS, Blom N. Bacterial diversity in snow on North Pole ice floes. Extremophiles. 2014;18(6):945-51. 
38. Lipson DA, Schmidt SK. Seasonal changes in an alpine soil bacterial community in the Colorado Rocky Mountains. Appl Environ Microbiol. 2004;70(5):2867-79.

39. Edwards KA, McCulloch J, Kershaw GP, Jefferies RLJSB. Biochemistry: Soil microbial and nutrient dynamics in a wet Arctic sedge meadow in late winter and early spring. 2006, 38(9):2843-2851.

40. Buckeridge KM, Grogan PJB. Deepened snow increases late thaw biogeochemical pulses in mesic low arctic tundra. 2010, $101(1-3): 105-121$.

41. Mallon CA, Poly F, Le Roux X, Marring I, van Elsas JD, Salles JFJE. Resource pulses can alleviate the biodiversity-invasion relationship in soil microbial communities. 2015, 96(4):915-926.

42. Fierer N, Schimel J, Holden P. Influence of drying-rewetting frequency on soil bacterial community structure. Microbial ecology. 2003;45(1):63-71.

43. Orwin KH, Dickie IA, Wood JR, Bonner KI, Holdaway RJ. Soil microbial community structure explains the resistance of respiration to a dry-rewet cycle, but not soil functioning under static conditions. Funct Ecol. 2016;30(8):1430-9.

44. Liu M, Bjørnlund L, Rønn R, Christensen S, Ekelund F. Disturbance promotes non-indigenous bacterial invasion in soil microcosms: analysis of the roles of resource availability and community structure. PloS one 2012, 7(10).

45. De Roy K, Marzorati M, Negroni A, Thas O, Balloi A, Fava F, Verstraete W, Daffonchio D, Boon N. Environmental conditions and community evenness determine the outcome of biological invasion. Nature communications. 2013;4(1):1-5.

46. Jousset A, Schulz W, Scheu S, Eisenhauer NJTIj. Intraspecific genotypic richness and relatedness predict the invasibility of microbial communities. 2011, 5(7):1108-1114

47. Acosta F, Zamor RM, Najar FZ, Roe BA, Hambright KD: Dynamics of an experimental microbial invasion. Proceedings of the National Academy of Sciences 2015, 112(37):11594-11599.

48. Li S-p, Tan J, Yang X, Ma C, Jiang L. Niche and fitness differences determine invasion success and impact in laboratory bacterial communities. ISME J. 2019;13(2):402-12.

49. van Elsas JD, Chiurazzi M, Mallon CA, Elhottovā D, Krištůfek V, Salles JF: Microbial diversity determines the invasion of soil by a bacterial pathogen. Proceedings of the National Academy of Sciences 2012, 109(4):1159-1164.

50. Mallon CA, Le Roux X, Van Doorn G, Dini-Andreote F, Poly F, Salles J: The impact of failure: unsuccessful bacterial invasions steer the soil microbial community away from the invader's niche. The ISME journa/ 2018, 12(3):728-741.

51. Bintanja R, Selten FJN. Future increases in Arctic precipitation linked to local evaporation and sea-ice retreat. 2014, 509(7501):479-482.

52. Bintanja R, Andry OJNCC. Towards a rain-dominated Arctic. 2017, 7(4):263-267.

53. Wipf S, Rixen CJPR. A review of snow manipulation experiments in Arctic and alpine tundra ecosystems. 2010, 29(1):95-109.

54. Malard LA, Pearce DA. Microbial diversity and biogeography in Arctic soils. Environmental microbiology reports. 2018;10(6):611-25.

55. Chu H, Fierer N, Lauber CL, Caporaso JG, Knight R, Grogan P. Soil bacterial diversity in the Arctic is not fundamentally different from that found in other biomes. Environ Microbiol. 2010;12(11):2998-3006.

56. Torsvik V, Øvreås L: Microbial diversity, life strategies, and adaptation to life in extreme soils. In: Microbiology of extreme soils. Springer; 2008 : $15-43$.

57. Glenn AR, Dilworth MJ: Soil acidity and the microbial population: Survival and growth of bacteria in low pH. In: Plant-soil interactions at low pH. Springer; 1991: 567-579.

58. Horikoshi K. Alkaliphiles: some applications of their products for biotechnology. Microbiology molecular biology reviews. 1999;63(4):735-50.

59. Winther J-G, Godtliebsen F, Gerland S, Isachsen PEJG, Change P. Surface albedo in Ny-Ålesund, Svalbard: variability and trends during $1981-1997$. 2002, 32(2-3):127-139.

60. Foster JJA, Research A. The significance of the date of snow disappearance on the Arctic tundra as a possible indicator of climate change. 1989, 21(1):60-70.

61. Soulides D, Allison F. Effect of drying and freezing soils on carbon dioxide production, available mineral nutrients, aggregation, and bacterial population. Soil Sci. 1961;91(5):291-8.

62. Yanai Y, Toyota K, Okazaki M. Effects of successive soil freeze-thaw cycles on soil microbial biomass and organic matter decomposition potential of soils. Soil science plant nutrition. 2004;50(6):821-9.

63. Hossain M, Chen W, Zhang YJIpia: Bulk density of mineral and organic soils in the Canada's arctic and sub-arctic. 2015, 2(3-4):183-190.

64. Marsh P, Woo MKJWRR: Wetting front advance and freezing of meltwater within a snow cover: 1. Observations in the Canadian Arctic. 1984, 20(12):1853-1864.

65. Nicol GW, Leininger S, Schleper C, Prosser Jl. The influence of soil pH on the diversity, abundance and transcriptional activity of ammonia oxidizing archaea and bacteria. Environ Microbiol. 2008;10(11):2966-78.

66. Caporaso JG, Lauber CL, Walters WA, Berg-Lyons D, Lozupone CA, Turnbaugh PJ, Fierer N, Knight R: Global patterns of 16S rRNA diversity at a depth of millions of sequences per sample. Proceedings of the National Academy of Sciences 2010:201000080.

67. Callahan BJ, McMurdie PJ, Rosen MJ, Han AW, Johnson AJA. Holmes SPJNm: DADA2: high-resolution sample inference from Illumina amplicon data. 2016, 13(7):581.

68. Pruesse E, Quast C, Knittel K, Fuchs BM, Ludwig W, Peplies J, Glöckner FO. SILVA: a comprehensive online resource for quality checked and aligned ribosomal RNA sequence data compatible with ARB. Nucleic acids research. 2007;35(21):7188-96. 
69. Quast C, Pruesse E, Yilmaz P, Gerken J, Schweer T, Yarza P, Peplies J, Glöckner FOJNar: The SILVA ribosomal RNA gene database project: improved data processing and web-based tools. 2012, 41(D1):D590-D596.

70. Suzuki MT, Taylor LT, DeLong EF: Quantitative analysis of small-subunit rRNA genes in mixed microbial populations via 5'-nuclease assays. Applied and environmental microbiology 2000, 66(11):4605-4614.

71. Dixon P. VEGAN, a package of R functions for community ecology. J Veg Sci. 2003;14(6):927-30.

72. McMurdie PJ, Holmes S. phyloseq: an R package for reproducible interactive analysis and graphics of microbiome census data. PloS one. 2013;8(4):e61217.

73. Wickham H: ggplot2: elegant graphics for data analysis: Springer; 2016.

74. Davis NM, Proctor DM, Holmes SP, Relman DA, Callahan BJJM. Simple statistical identification and removal of contaminant sequences in marker-gene and metagenomics data. 2018, 6(1):226.

75. Kim B-R, Shin J, Guevarra RB, Lee JH, Kim DW, Seol K-H, Lee J-H, Kim HB, Isaacson RE. Deciphering diversity indices for a better understanding of microbial communities. J Microbiol Biotechnol. 2017;27(12):2089-93.

76. Paliy O, Shankar V. Application of multivariate statistical techniques in microbial ecology. Molecular ecology. 2016;25(5):1032-57.

77. Ramette A. Multivariate analyses in microbial ecology. FEMS Microbiol Ecol. 2007;62(2):142-60.

78. Morton JT, Toran L, Edlund A, Metcalf JL, Lauber C, Knight R. Uncovering the horseshoe effect in microbial analyses. Msystems 2017, 2(1).

79. Schmidt S, Lipson D. Microbial growth under the snow: implications for nutrient and allelochemical availability in temperate soils. Plant Soil. 2004;259(1-2):1-7.

80. Li W, Stevens MHH. Fluctuating resource availability increases invasibility in microbial microcosms. Oikos. 2012;121(3):435-41.

81. Van Nevel S, De Roy K, Boon N. Bacterial invasion potential in water is determined by nutrient availability and the indigenous community. FEMS Microbiol Ecol. 2013;85(3):593-603.

82. Ho A, Di Lonardo DP, Bodelier PL. Revisiting life strategy concepts in environmental microbial ecology. FEMS Microbiol Ecol. 2017;93(3):fix006.

83. Costa OY, Raaijmakers JM, Kuramae EE. Microbial extracellular polymeric substances: ecological function and impact on soil aggregation. Frontiers in microbiology. 2018;9:1636.

84. Fierer N, Bradford MA, Jackson RB. Toward an ecological classification of soil bacteria. Ecology. 2007;88(6):1354-64.

85. Andrews JH, Harris RF: r-and K-selection and microbial ecology. In: Advances in microbial ecology. Springer; 1986: 99-147.

86. Litchman E. Invisible invaders: non-pathogenic invasive microbes in aquatic and terrestrial ecosystems. Ecology letters. 2010;13(12):1560-72.

87. Voroney R, Heck R: The soil habitat. In: Soil microbiology, ecology, and biochemistry. Edited by Paul EA: Academic Press; 2014: 15-39.

88. Morris SJ, Blackwood CB. The ecology of the soil biota and their function. Soil microbiology, ecology and biochemistry 2015:273-309.

89. Pandit SN, Kolasa J, Cottenie K. Contrasts between habitat generalists and specialists: an empirical extension to the basic metacommunity framework. Ecology. 2009;90(8):2253-62.

90. Graham EB, Stegen JC. Dispersal-based microbial community assembly decreases biogeochemical function. Processes. 2017;5(4):65.

91. Sriswasdi S, Yang C-c, Iwasaki W. Generalist species drive microbial dispersion and evolution. Nature communications. 2017;8(1):1-8.

92. Rousk J, Bååth E, Brookes PC, Lauber CL, Lozupone C, Caporaso JG, Knight R, Fierer N. Soil bacterial and fungal communities across a pH gradient in an arable soil. ISME J. 2010;4(10):1340-51.

93. Beales N. Adaptation of microorganisms to cold temperatures, weak acid preservatives, low pH, and osmotic stress: a review. Compr Rev Food Sci Food Saf. 2004;3(1):1-20.

94. Ward NL, Challacombe JF, Janssen PH, Henrissat B, Coutinho PM, Wu M, Xie G, Haft DH, Sait M, Badger J. Three genomes from the phylum Acidobacteria provide insight into the lifestyles of these microorganisms in soils. Appl Environ Microbiol. 2009;75(7):2046-56.

95. Robson A, Abbott L. The effect of soil acidity on microbial activity in soils. Soil acidity and plant growth 1989:139-165.

96. Kunhikrishnan A, Thangarajan R, Bolan N, Xu Y, Mandal S, Gleeson D, Seshadri B, Zaman M, Barton L, Tang C: Functional relationships of soil acidification, liming, and greenhouse gas flux. In: Advances in agronomy. vol. 139: Elsevier; 2016: 1-71.

97. Muhlbachova G, Tlustos P. Effects of liming on the microbial biomass and its activities in soils long-term contaminated by toxic elements. Plant Soil Environment. 2006;52(8):345.

98. Guo A, Ding L, Tang Z, Zhao Z, Duan G. Microbial response to CaCO3 application in an acid soil in southern China. J Environ Sci. 2019;79:321-9.

99. Drake JJ, Moore T. Snow pH and dust loading at Schefferville, Quebec. Canadian Geographer/Le Géographe canadien. 1980;24(3):286-91.

100. Newton A. Red-coloured snow algae in Svalbard-some environmental factors determining the distribution of Chlamydomonas nivalis (Chlorophyta volvocales). Polar Biol. 1982;1(3):167-72.

101. Kol E, Taylor WR. The snow and ice algae of Alaska. Smithsonian miscellaneous collections 1942.

102. Li X, Li Z, Ding Y, Liu S, Zhao Z, Luo L, Pang H, Li C, Li H, You X: Seasonal variations of pH and electrical conductivity in a snow-firn pack on Glacier No. 1, eastern Tianshan, China. Cold Regions Science and Technology 2007, 48(1):55-63.

103. Zhang Y, Xiu G, Wu X, Moore CW, Wang J, Cai J, Zhang D, Shi C, Zhang R. Characterization of mercury concentrations in snow and potential sources, Shanghai, China. Science of the total environment. 2013;449:434-42. 


\section{Figures}

\section{Snow melt}

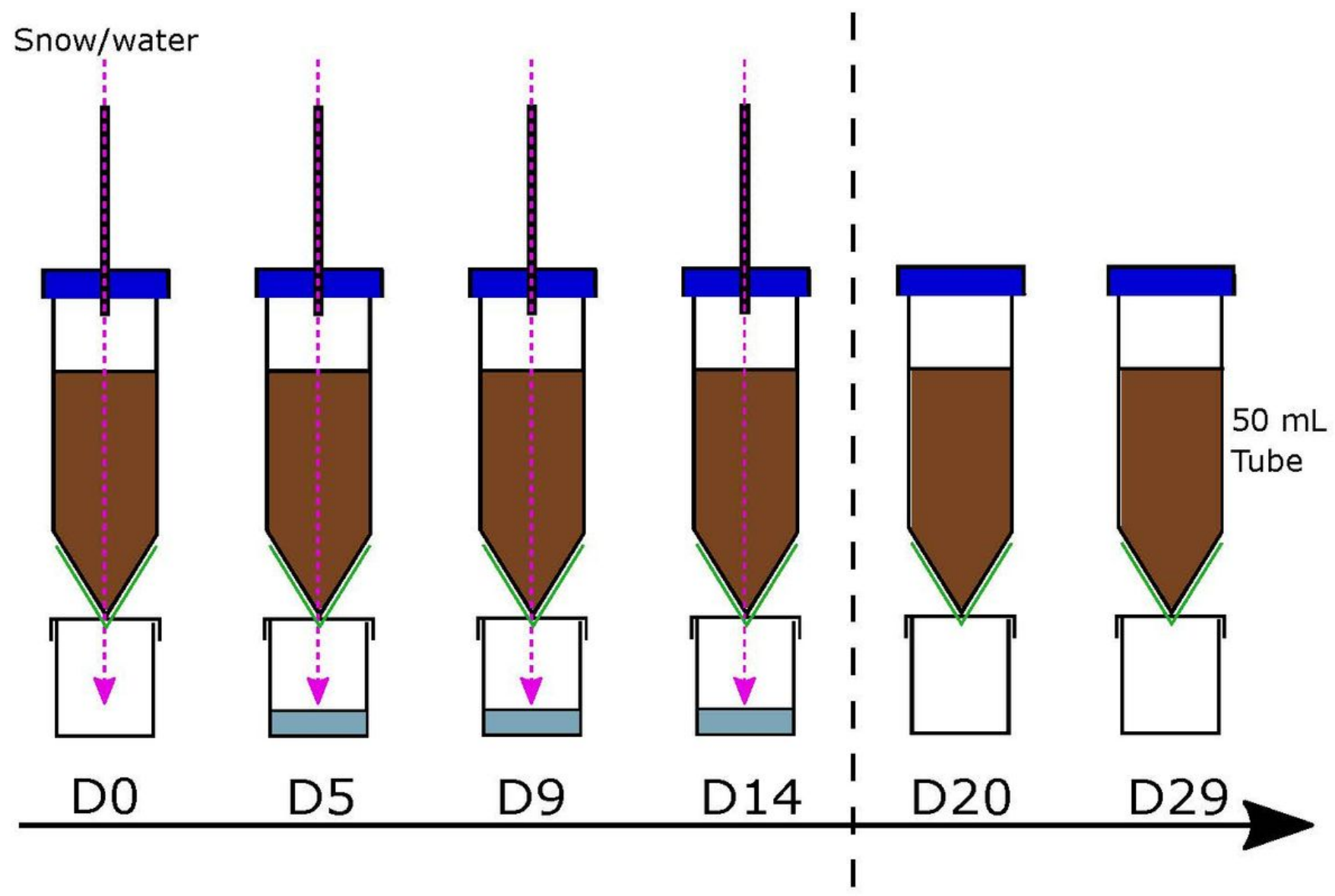

\section{IEnd of snow melt} I 

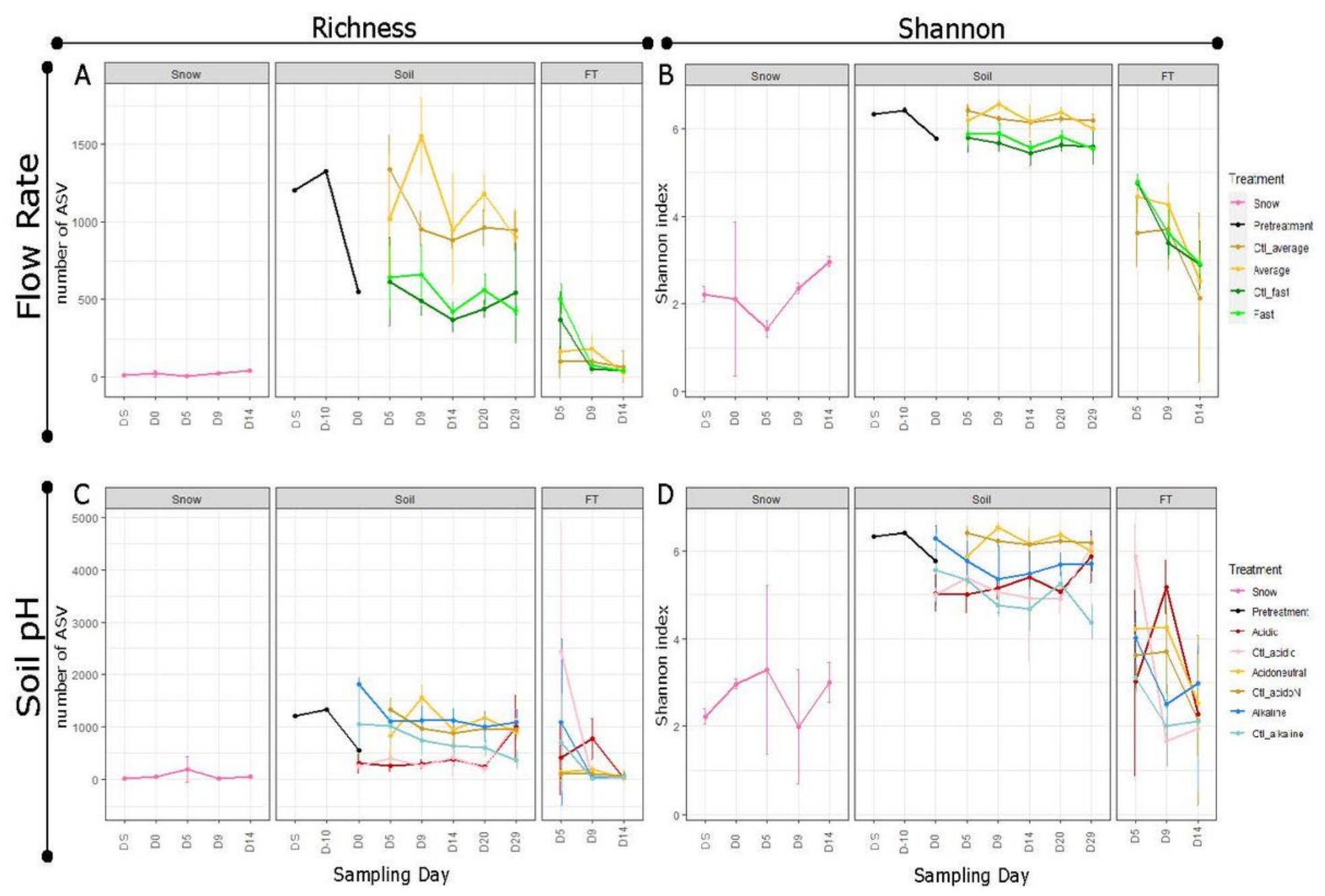

Figure 2

Alpha diversity by experiment, treatment, sample type and day of sampling. (A) Observed number of ASVs (Richness) and (B) Diversity with the Shannon index in different flow rate experiments. (C) Observed number of ASVs (Richness) and (D) Diversity with the Shannon index in different soil pH experiments. The shades of yellow correspond to the average and acidoneutral controls (Ctl) and treatments, resulting from the same microcosm. 
Flow Rate
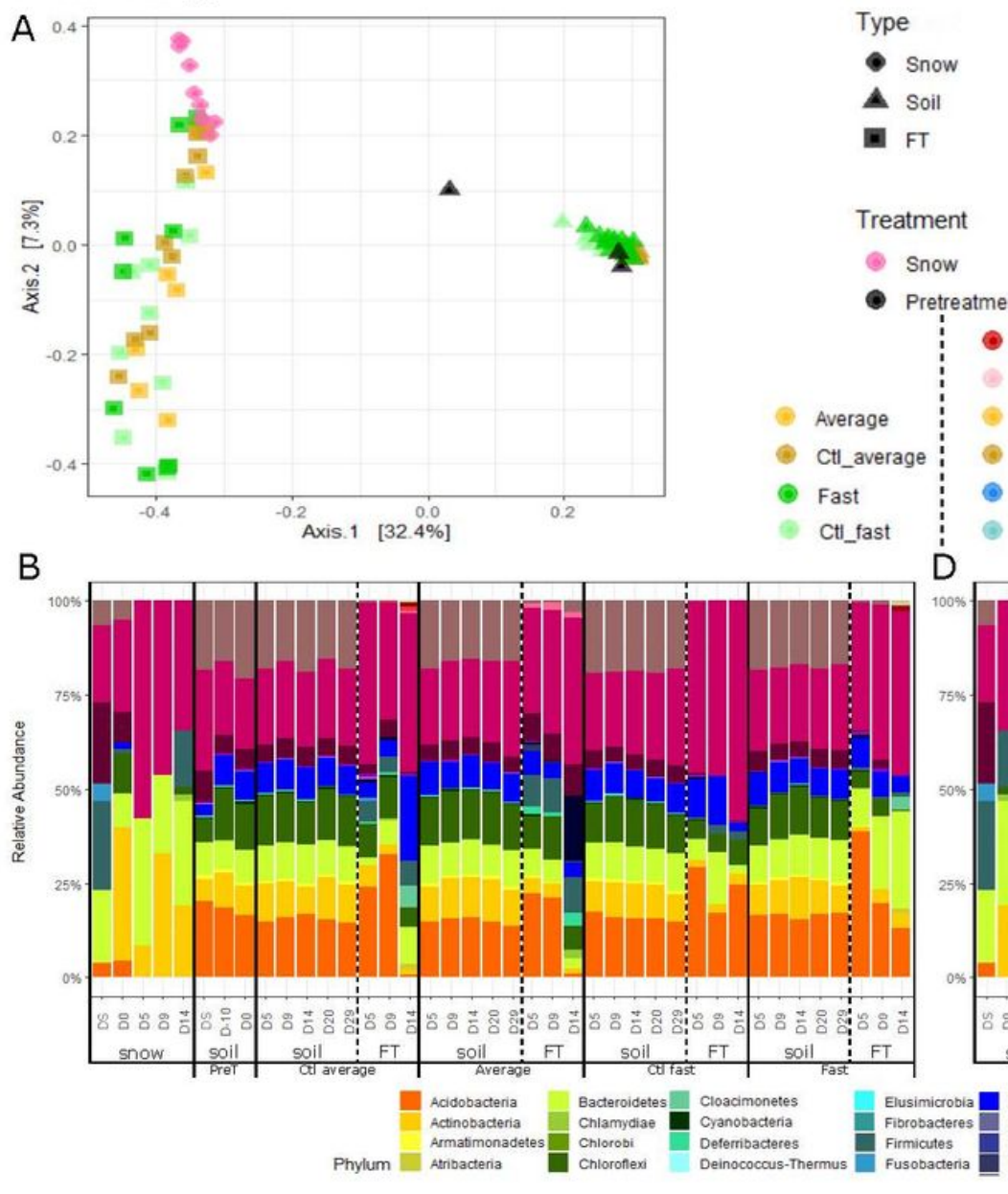

\section{Soil pH}

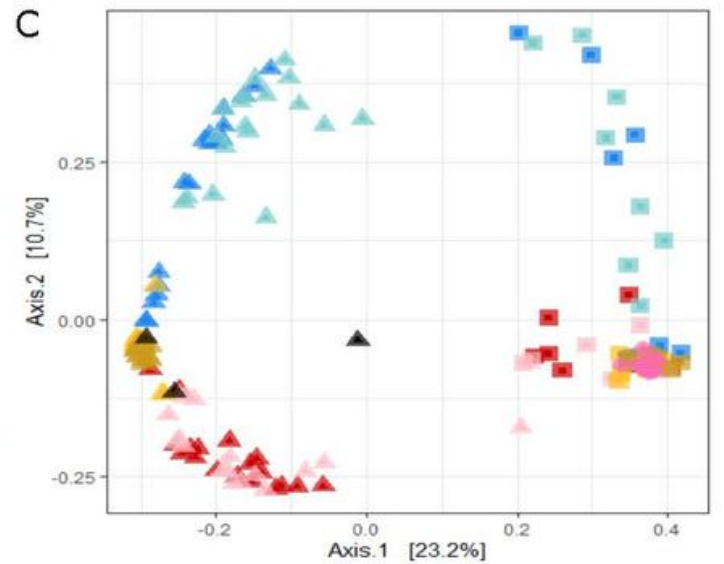

Type

- Snow

a FT

Treatment

Snow

- Pretreatment

$$
\begin{aligned}
& \text { - Acidic } \\
& \text { Ctl_acidic } \\
& \text { Acidoneutral } \\
& \text { Ctl_acidon } \\
& \text { - Alkaline }
\end{aligned}
$$

(
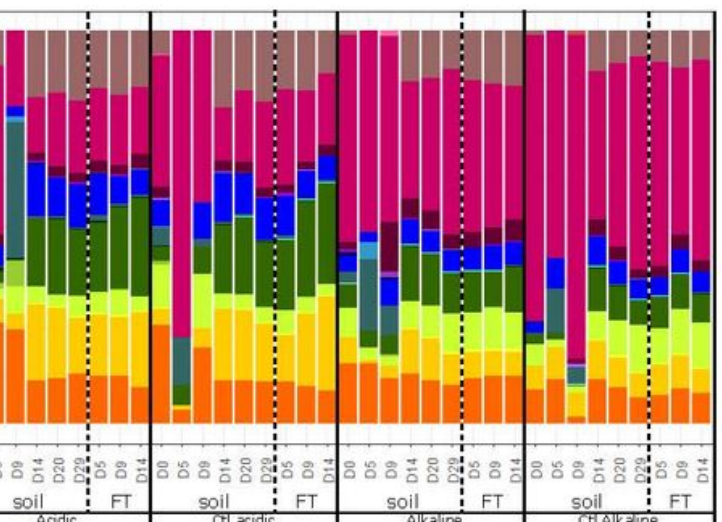

8 8.

Gemmatimonadetes
Ignavibacteriae Ignavibacteriae
Latescibacteria Lentisphaerae Proteobacteria

Figure 3

PCoA and community composition at the phylum level, by experiment, treatment, sample type and day of sampling. (A) PCoA and (B) Community composition of flow rate microcosms. (C) PCoA and (D) Community composition of soil pH microcosms. Pretreatment (PreT) includes the day of field sampling (DS), the day of microcosm set-up (D-10) and D0 for the flow rate experiment as the soil was not yet treated in any way. 
A. Fast

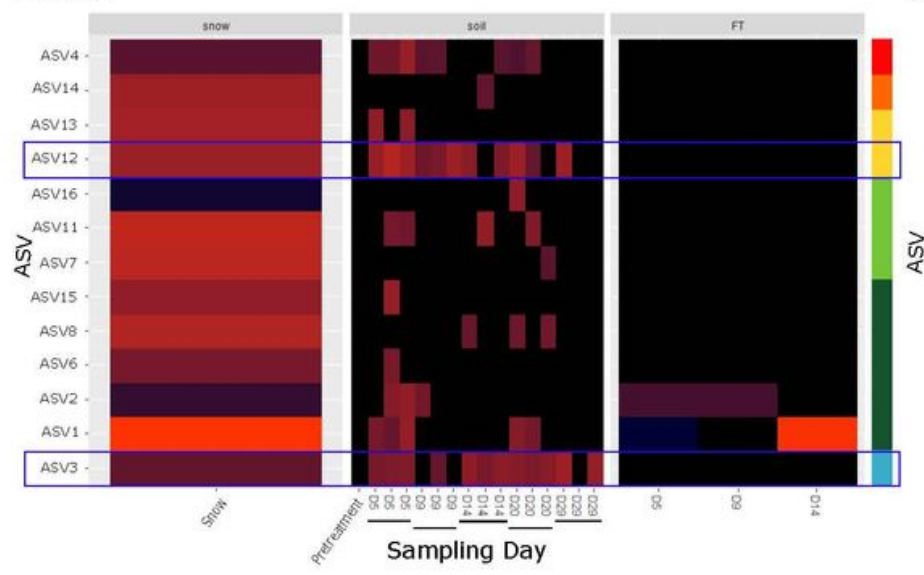

C. Acidic

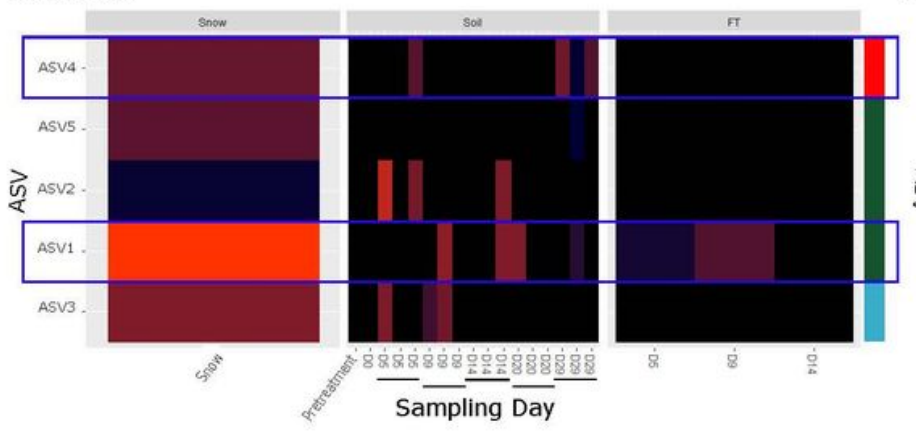

Gammaproteobacteria (Proteobacteria) Deltaproteobacteria (Proteobacteria) Betaproteobacteria (Proteobacteria)

Alphaproteobacteria (Proteobacteria) Sphingobacteriia (Bacteroidetes) Flavobacteriia (Bacteroidetes) Potentially successful colonists

\section{B. Average/Acidoneutral}

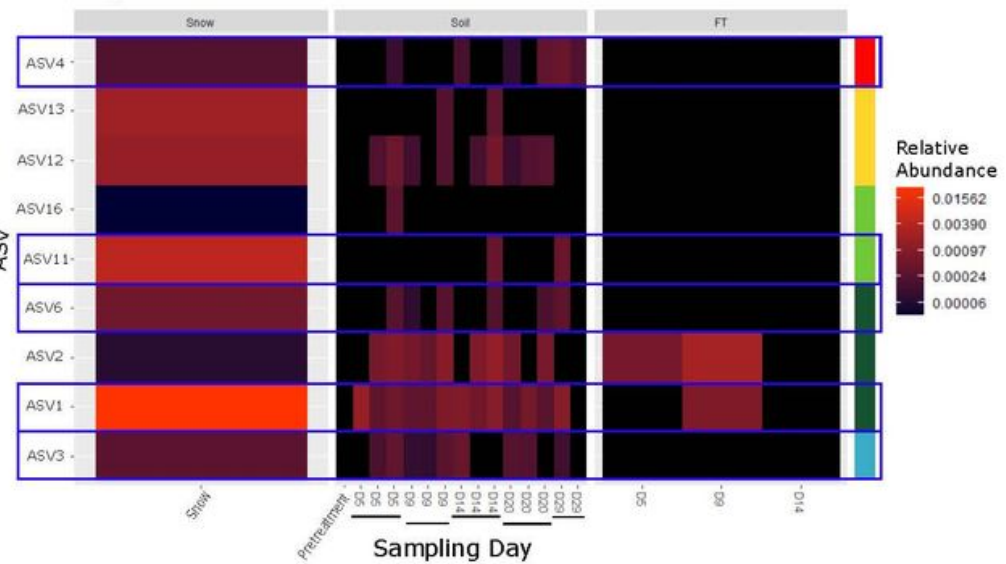

D. Alkaline

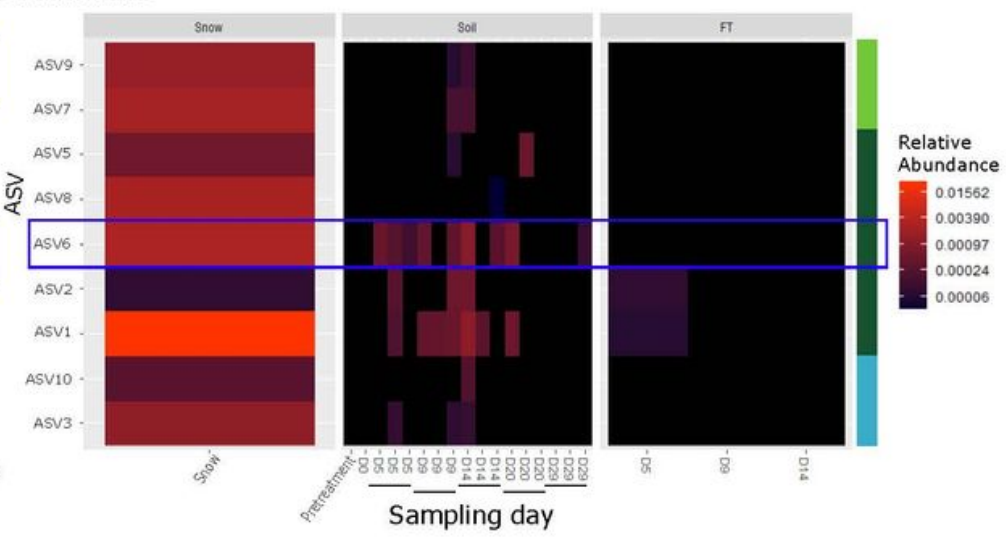

Figure 4

Heatmap of invaders of (A) the fast flow, (B) the average flow/acidoneutral, (C) the acidic and (D) the alkaline experiments where each row corresponds to an ASV. The coloured bar indicates the taxonomy associated to each ASV at the class level. Blue boxes highlight potentially successful colonists identified across multiple days and still present on D29. Black bars indicate replicate microcosms.

\section{Supplementary Files}

This is a list of supplementary files associated with this preprint. Click to download.

- Supplementary1.docx 